\title{
Effects of feeding on the swimming activity and growth of Ophiocephalus striatus
}

\author{
E. VIVEKANANDAN \\ Zoology Department, Madurai University P.G. Centre, \\ Sri Palaniandavar Arts College, Palni, Tamil Nadu, India
}

(Accepted 21 January 1975)

\begin{abstract}
Swimming activity of the obligatory air-breathing fish Ophiocephalus striatus reared in cylindrical aquaria on different rations $(0-43.3 \mathrm{mg} / \mathrm{g} /$ day $)$ increased from $58 \mathrm{~m} /$ day for the starving group to $439 \mathrm{~m} /$ day for the group fed a maximum ration. Swimming speed also increased from $2.4 \mathrm{~cm} / \mathrm{sec}$ in the former group to $5.2 \mathrm{~cm} / \mathrm{sec}$ in the latter group. Owing to sustained swimming activity and the consequent fatigue, the test individuals ' hung ' to the surface for a definite interval. Duration of surface 'hanging' increased from $3 \cdot 2 \mathrm{~h} /$ day to $15.8 \mathrm{~h} /$ day with decreasing ration. The group receiving $25.5 \mathrm{mg} / \mathrm{g} /$ day converted most efficiently $(28 \%)$. The maintenance energy cost is equivalent to $10 \mathrm{mg} / \mathrm{g} /$ day and dry substance equivalent to 5 or $12 \mathrm{mg} / \mathrm{g} /$ day was expended on the sustained swimming activity by the fish receiving the optimum $(25 \mathrm{mg} / \mathrm{g} /$ day $)$ or the maximum $(43 \mathrm{mg} / \mathrm{g} /$ day $)$ ration.
\end{abstract}

\section{INTRODUCTION}

Food quantity and quality can affect the growth rate considerably. When growth rate is plotted against ration, one can obtain:

(i) Maintenance ration, in which the fish neither loses nor gains body weight.

(ii) Optimum ration, in which the fish exhibits maximum conversion efficiency.

(iii) Maximum ration, which the fish consumes under the given experimental conditions. To optimize food conversion in fish culture practices, one requires basic knowledge of the metabolic demands of maintenance and other activities. While there are several publications concerning the effect of feeding rates on the growth of fish (Gerking, 1955, 1971; Pandian, 1967b; Brett, Shelbourn \& Shoop, 1969; Pandian \& Raghuraman, 1972), effect of different rations on the swimming activity of fish is lacking.

Kinne (1960) regarded feeding rate and conversion efficiency estimates as better parameters for assessing metabolic rates and efficiencies. Reared in aquaria containing different depths of water, the obligatory air-breathing fish $O$. striatus swam longer or shorter distance to exchange atmospheric air; such a design of experiment permitted Pandian \& Vivekanandan (1976) to measure food intake, growth and sustained active metabolism on a long term basis. They found that the fish in deeper waters consumed significantly more food, swam longer distances and dissipated more energy on metabolism and swimming activity. As a continuation of that research, this experiment was carried out to study whether ration level controls the swimming activity or vice versa.

\section{MATERIALS AND METHODS}

Fingerlings of Ophiocephalus striatus ( $900 \pm 65 \mathrm{mg} ; 4.5 \pm 0.8 \mathrm{~cm}$ body length) were collected from the Lake Idumban (Palni) while swimming alongside their parents; they therefore 
belonged to the same brood. They were brought to the laboratory and acclimatized to laboratory conditions and a feeding schedule. For experiments, cylindrical aquaria $(10 \mathrm{~cm}$ diameter; capacity: 4.51 ) were chosen to minimize swimming activity in horizontal direction. As the aquaria contained a constant depth of $15.5 \mathrm{~cm}$ water, the test individuals travelled about six times their body length, when they returned to the bottom after each surfacing.

O. striatus is known to consume $43 \mathrm{mg}$ dry food/g live fish/day, when fed twice a day for a period of $2+2 \mathrm{~h}$ in aquaria containing $15.5 \mathrm{~cm}$ water depth at $27^{\circ} \mathrm{C}$ (Pandian \& Vivekanandan, 1975). Six different rations ranging from $0-60 \mathrm{mg}$ dry food/g live fish/day were offered. The test fish groups, each comprising three individuals, were fed twice a day on Tilapia mossambica muscle; the groups receiving $6 \cdot 0-25 \cdot 5 \mathrm{mg} / \mathrm{g} /$ dayconsumed the ration immediately, or in some cases, within $30 \mathrm{~min}$; the last group, which received the maximum ration of $60 \mathrm{mg} / \mathrm{g} /$ day for a total period of $4 \mathrm{~h}$ (between 09.00 and $11.00 \mathrm{~h}$ and 17.00 and $19.00 \mathrm{~h}$ ), however, consumed only $43.3 \mathrm{mg} / \mathrm{g} / \mathrm{day}$. Care was taken to collect the unfed remains with a pipette. Suitable corrections were made for body fluids lost by the muscle pieces during the time they were left in the aquaria.

Faeces were collected by filtering the entire aquaria once every 5 days. 'Sacrifice method' (Maynard \& Loosli, 1962) was used for determining the water content of the test individuals before commencing the experiments. Estimations of dissolved oxygen content and $\mathrm{pH}$ of the water in each aquarium were made once every 5 days; the oxygen values ranged between 4.3 and $4.9 \mathrm{ml} / 1$ and the $\mathrm{pH}$ values between $7 \cdot 3$ and 8.6 .

Experiments were conducted in a laboratory where, except for feeding and observations, there was no disturbance. The number of visits to the surface of the water by each test individual was observed for a known period of time (about $15 \mathrm{~min}$ ), 4 times a day at $07.00 \mathrm{~h}$, $13.00 \mathrm{~h}, 19.00 \mathrm{~h}$ and $23.00 \mathrm{~h}$. The distance travelled per individual per day was estimated multiplying the mean number of visits per unit observation time with twice the depth of water. Observations were made daily for a period of 21 days; since observations were made on three individuals, the average performance is based on a minimum of 250 observations (Table I).

\section{RESULTS AND DISCUSSION}

As the ration increased, Ophiocephalus striatus visited the surface more frequently in order to obtain atmospheric air (Table I, Fig. 1). Correspondingly, the distance travelled by these groups increased from $170.4 \mathrm{~m} /$ day $-506.9 \mathrm{~m} /$ day. Pandian \& Vivekanandan (1976), who exposed O. striatus $(0.75 \mathrm{~g})$ to a water depth of $15.5 \mathrm{~cm}$, reported that the swimming activity increased from $138.4 \mathrm{~m} /$ day for a starved group to $468 \mathrm{~m} /$ day for a feeding group. The small differences in swimming activity observed among the respective groups studied in this investigation $(0.90 \mathrm{~g})$ and that previously described $(0.75 \mathrm{~g})$ by Pandian \& Vivekanandan (1976) were perhaps due to the size of the fish.

Surfacing by $O$. striatus consists of: (i) A period during which the fish swims upwards, (ii) a short. period, usually lasting for some $2 \mathrm{sec}$, during which time the fish obtains atmospheric air, and (iii) a period, when the fish returns to the bottom. Pandian \& Vivekanandan (1976) observed that at times $O$. striatus ' hangs' to the surface and postpones returning to the bottom. They stated that in addition to the branchial respiration, ' hanging ' to the surface permitted the obligatory air-breathing fish to exchange gas without undertaking vertical movement. Such a period of rest may be regarded as a condition, during which the resulting 'fatigue' has reached the maximum threshold (Brett, 1972) and the fish is paying off the accumulated 'oxygen debt', i.e. it exchanges respiratory gases without involving swimming activities.

In order to assess the approximate duration of ' hanging' in the individuals receiving different rations, simultaneous observations were made on each individual for 60 min per day between $11.00 \mathrm{~h}-11.30 \mathrm{~h}$ and $19.00 \mathrm{~h}-19.30 \mathrm{~h}$. The duration of ' hanging' 
TABLE I. Effects of feeding rates and swimming activity on different metabolic parameters in Ophiocephalus striatus. Each value represents the average performance of 3 individuals (mean $\pm \mathrm{SD}$ ) maintained for a period of 21 days at $27^{\circ} \mathrm{C}$

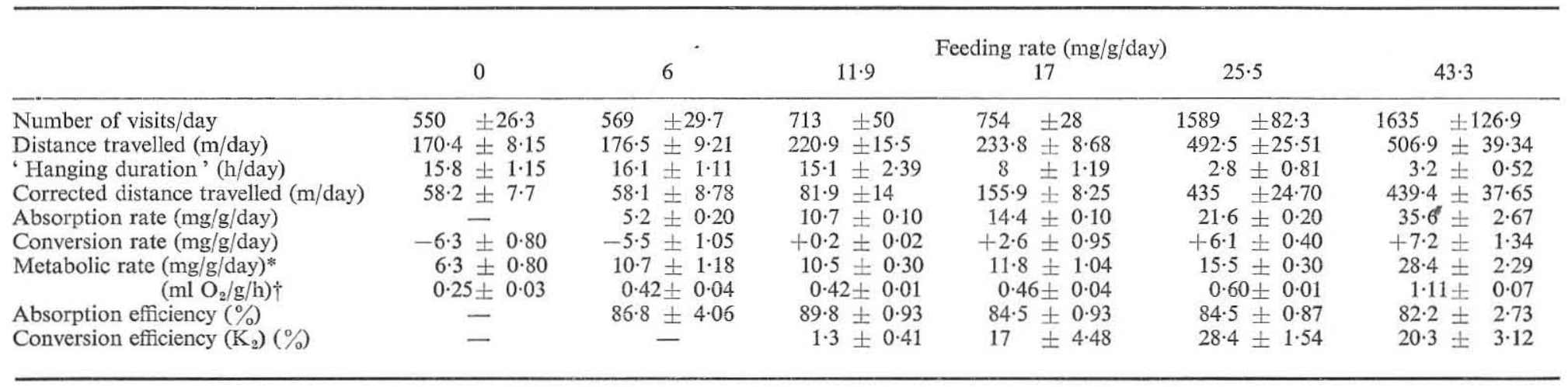

*Calculated subtracting the dry weight equivalents of conversion rate from that of absorption rate

$\uparrow$ Calculated considering the expenditure of $4.8 \mathrm{cal}$ energy as equivalent to $1 \mathrm{ml}$ of $\mathrm{O}_{2}$ uptake (Engelmann, 1966); calorific value of $O$. striatus reported to be $4500 \mathrm{cal} / \mathrm{g}$ dry weight (Pandian, 1967a) 


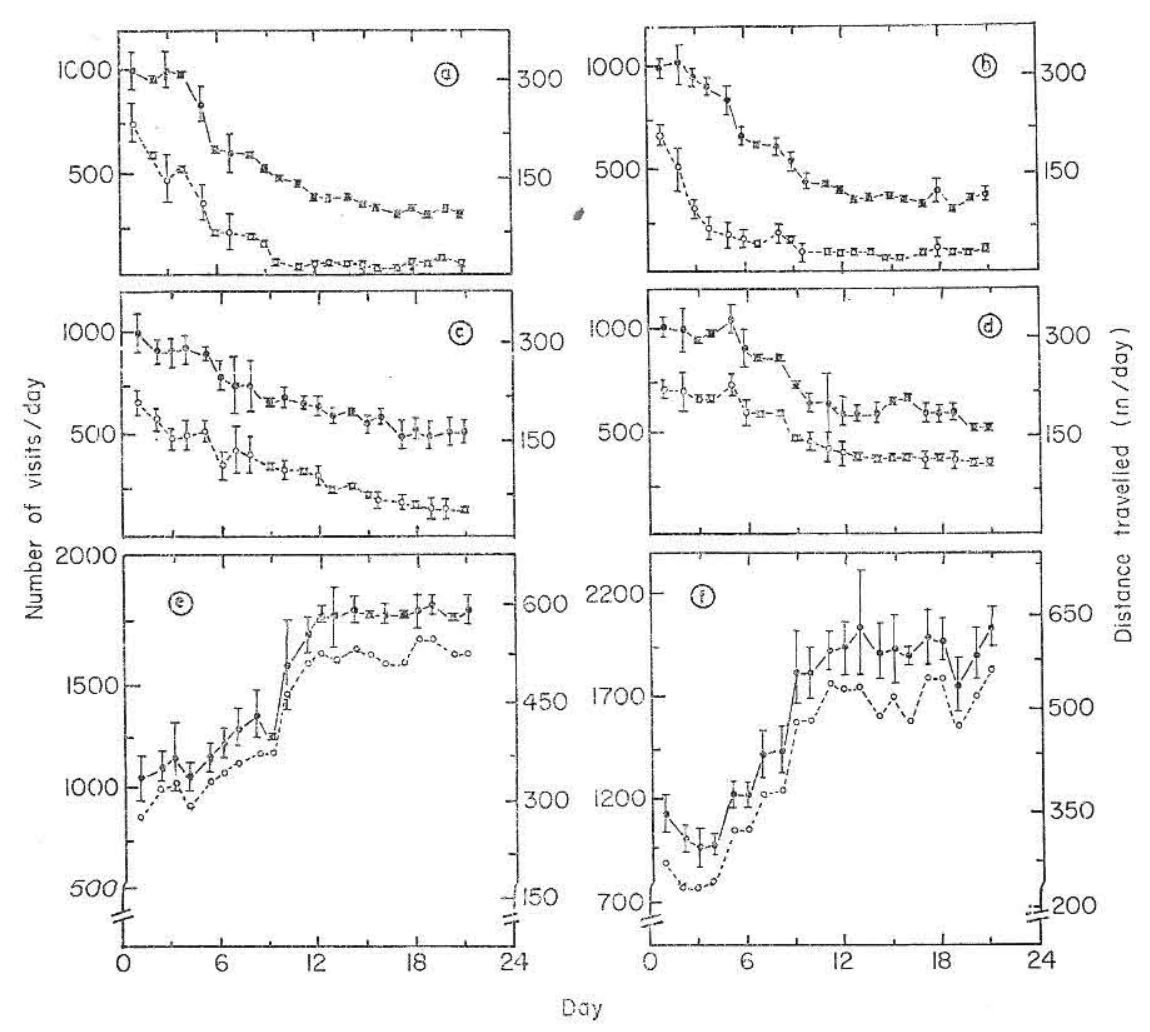

FIG. 1. Effects of feeding rate on the number of visits to the surface for exchange of atmospheric air and the distance travelled by Ophiocephalus striatus reared in aquaria containing $15.5 \mathrm{~cm}$ depth of water at $27^{\circ} \mathrm{C}$. (a)-(f) pertain to the groups receiving $0,6,11 \cdot 9,17,25 \cdot 5$ and $43 \cdot 3 \mathrm{mg}$ dry food/g live fish/day, respectively. Each value represents the average performance of three individuals observed 4 times a day for a total period of $1 \mathrm{~h}$ per day. Upper (--) and lower (-- $\mathrm{O}_{--\mathrm{O}--)}$ ) lines indicate the uncorrected and corrected (for hanging durations) distance travelled by the fish. The vertical lines (not indicated in the lower lines of the panels $\mathrm{e}$ and $\mathrm{f}$ for clarity) indicate SD.

was $3 \cdot 2 \mathrm{~h} /$ day for the group which was fed the maximum ration (Table I). This value compares favourably with the value $(3 \mathrm{~h} /$ day) reported by Pandian \& Vivekanandan (1976) for a feeding group of $O$. striatus exposed to $15.5 \mathrm{~cm}$ depth of water. The duration of 'hanging' increased from $3 \cdot 2 \mathrm{~h} /$ day to $8 \mathrm{~h}$ /day in the $17 \mathrm{mg} / \mathrm{g} /$ day group, and subsequently to $16 \mathrm{~h} /$ day in the groups receiving a ration of 0 or $11.9 \mathrm{mg}$ / $\mathrm{g} /$ day (Table I). A ration below $25.5 \mathrm{mg} / \mathrm{g} /$ day significantly extended the ' hanging' periods.

Using the values obtained for the 'hanging' duration, the actual period during which the fish exhibited swimming activity was assessed (Table I). There was no significant difference in the corrected distance travelled (Fig. 1, lower lines) between the groups receiving 25.5 and $43.3 \mathrm{mg} / \mathrm{g} /$ day (Fig. 2); the same was true between the groups receiving 0 and $6 \mathrm{mg} / \mathrm{g} /$ day. The swimming activity increased logarithmically from $58 \mathrm{~m} /$ day in group receiving $6 \mathrm{mg} / \mathrm{g} /$ day to $435 \mathrm{~m} /$ day in those feeding $25.5 \mathrm{mg}$ / $\mathrm{g} /$ day and levelled off at $440 \mathrm{~m} /$ day in the group receiving $43.3 \mathrm{mg} / \mathrm{g} /$ day.

On the first day of the experiment, the fish swam an average distance of $320 \mathrm{~m} /$ day (Fig. 1). As its mean 'hanging' duration was $7 \cdot 1 \mathrm{~h} /$ day, the corrected distance 


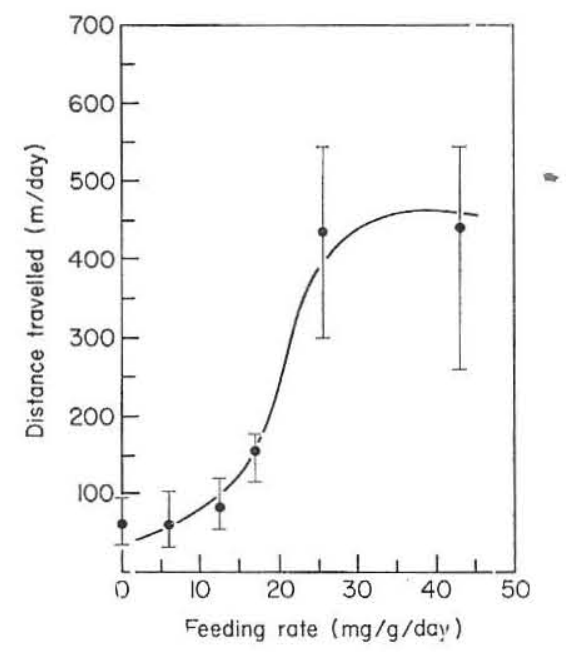

FIG. 2. Effect of feeding rate on the mean distance travelled by the obligatory air-breathing fish Ophiocephalus striatus exposed to $15.5 \mathrm{~cm}$ depth of water at $27^{\circ} \mathrm{C}$. Each value represents the mean of 250 observations. The vertical line indicates the actual range of values recorded.

travelled was only $225 \mathrm{~m} /$ day. In the groups receiving rations less than $17 \mathrm{mg} / \mathrm{g} /$ day, the ' hanging' duration increased from $8.2 \mathrm{~h}$ /day on the first day of starvation to over $16 \mathrm{~h} /$ day on the tenth, fifteenth and eighteenth day in the groups receiving 0,6 , and $11.9 \mathrm{mg} / \mathrm{g} /$ day, respectively. The 'hanging' time remained constant during the rest of the experiment (Fig. 3). On the other hand, the 'hanging' duration oscillated around $8 \mathrm{~h}$ /day in the group receiving $17 \mathrm{mg} / \mathrm{g} /$ day and $3 \mathrm{~h}$ /day in groups receiving rations over $25.5 \mathrm{mg} / \mathrm{g} /$ day. In general, the effect of ration level on duration of ' hanging' was reflected by the test groups after a period about 7 days.

This delay in the effect of different rations was also observed on swimming activity. The fish receiving a ration of less than $12 \mathrm{mg} / \mathrm{g} /$ day swam $240 \mathrm{~m} /$ day on the first day of the experiment; the distance rapidly decreased to $75 \mathrm{~m} /$ day on the sixth day of the experiment and was constant thereafter. Those receiving over $25.5 \mathrm{mg} / \mathrm{g} /$ day increased their swimming activity from $270 \mathrm{~m} /$ day on the first day of the experiment to $430 \mathrm{~m}$ /day on the ninth day of the experiment and maintained their activity at that level (Fig. 1).

Pandian \& Vivekanandan (1976) made similar observations in feeding and starving $O$. striatus exposed to different depths of water. They observed starving $O$. striatus at $31 \mathrm{~cm}$ depth decreased their swimming activity from $378 \mathrm{~m} /$ day on the first day of the experiment to $316 \mathrm{~m} /$ day on the fifth day, whereas feeding fish increased the swimming activity from $1035 \mathrm{~m} /$ day on the first day to $1130 \mathrm{~m} /$ day on the eighth day of the experiment. Similar observations were made on the swimming abilities of feeding and starving larvae of the largemouth bass Micropterus salmoides (Laurence, 1972). They increased their swimming activity from $56 \mathrm{~m}$ /day on the first day to $492 \mathrm{~m}$ /day on the seventh day of test feeding; conversely an older starving larva swam $400 \mathrm{~m} /$ day on the second day of starvation and only $135 \mathrm{~m} /$ day on the seventh fasting day. Testing the sustained activity of some marine fish, Beamish (1964) observed a decrease in standard metabolism and swimming capacity.

The increase in the ability of the feeding fish and fish larvae to swim longer distances is understandable, as the conversion of food results in the accumulation of 

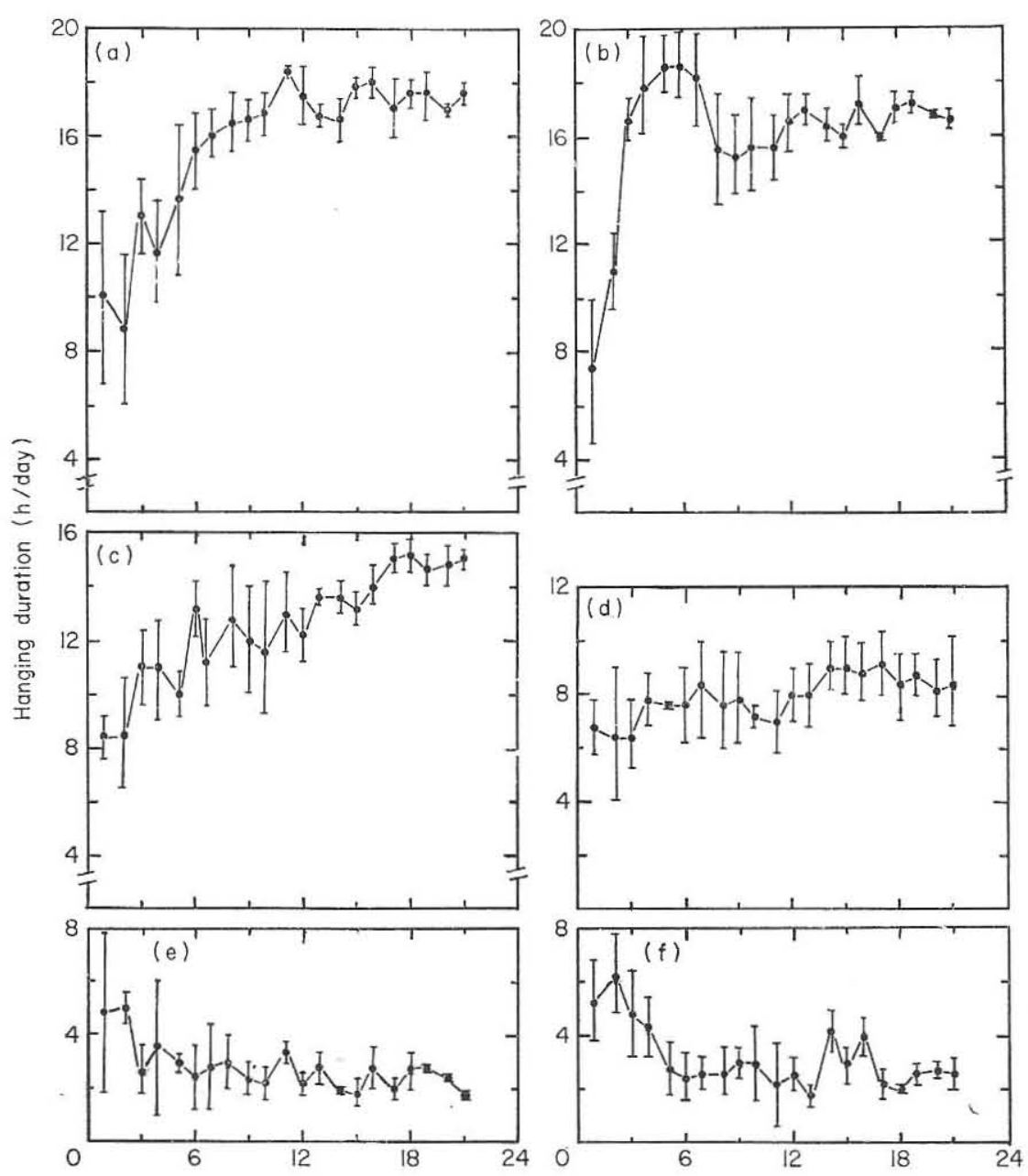

Day

FIG. 3. Effect of feeding rate on the 'hanging' duration by Ophiocephalus striatus reared in aquaria containing $15.5 \mathrm{~cm}$ depth of water at $27^{\circ} \mathrm{C}$. (a)-(f) pertain to the groups receiving $0,6,11.9$, $17,25.5$ and $43.3 \mathrm{mg}$ dry food/g live fish/day, respectively. Each value represents the average performance of three individuals observed twice a day for a total period of $1 \mathrm{~h}$ per day. The vertical lines indicate SD.

energy-releasing compounds in the muscle fibres. The nature of physiological mechanisms of sustained swimming in fish is determined by the ability of muscles to utilize their energy-releasing substances and by the rates at which these substances can be supplied and waste products removed from the muscles (Johnston \& Goldspink, 1973). Apparently, the muscles of starved fish do not have adequate energy-releasing substances to permit sustained swimming activity.

The inadequate store of energy-releasing substances and the inability to remove the waste products of the muscles in starved fish, not only inhibit sustained swimming activity but also decrease the swimming speed (Table II). As indicated previously, the time required for each surfacing increased from $54 \mathrm{sec}$ in groups receiving over $25.5 \mathrm{mg} / \mathrm{g} /$ day to $157 \mathrm{sec}$ in groups receiving less than $6 \mathrm{mg} / \mathrm{g} /$ day. Correspondingly, 
TABLE II. Effect of feeding rates on durations of swimming and resting in the fish Ophiocephalus striatus at $27^{\circ} \mathrm{C}$. Each mean value is based on 250 observations, each observation lasted for a minimum period of $15 \mathrm{~min}$.

\begin{tabular}{ccccc}
\hline $\begin{array}{c}\text { Feeding rate } \\
(\mathrm{mg} / \mathrm{g} / \mathrm{day})\end{array}$ & $\begin{array}{c}\text { Time required } \\
\text { for each } \\
\text { surfacing }(\mathrm{sec})\end{array}$ & $\begin{array}{c}\text { 'Resting duration' } \\
\text { in the bottom (sec) }\end{array}$ & $\begin{array}{c}\text { Swimming } \\
\text { duration }(\mathrm{sec})\end{array}$ & $\begin{array}{c}\text { Swimming } \\
\text { speed (cm/sec) }\end{array}$ \\
\hline $43 \cdot 3$ & $53 \pm 6 \cdot 8$ & $47 \pm 4$ & $6 \pm 2 \cdot 8$ & $5 \cdot 2 \pm 0 \cdot 11$ \\
$25 \cdot 5$ & $54 \pm 11 \cdot 1$ & $48 \pm 9 \cdot 5$ & $6 \pm 1 \cdot 6$ & $5 \cdot 2 \pm 0 \cdot 20$ \\
17 & $115 \pm 30 \cdot 9$ & $105 \pm 25 \cdot 1$ & $10 \pm 5 \cdot 8$ & $3 \cdot 1 \pm 0 \cdot 53$ \\
$11 \cdot 9$ & $121 \pm 21 \cdot 8$ & $112 \pm 16 \cdot 9$ & $9 \pm 4 \cdot 9$ & $3 \cdot 5 \pm 0 \cdot 63$ \\
6 & $152 \pm 29 \cdot 1$ & $139 \pm 23 \cdot 1$ & $13 \pm 6$ & $2 \cdot 4 \pm 0 \cdot 26$ \\
0 & $157 \pm 32 \cdot 9$ & $144 \pm 28 \cdot 6$ & $13 \pm 4 \cdot 3$ & $2 \cdot 4 \pm 0 \cdot 70$ \\
\hline
\end{tabular}

the duration of rest at the bottom increased from $47 \mathrm{sec}$ in the former groups to 144 in the latter. Furthermore the duration required by the test groups to swim a distance of $31 \mathrm{~cm}$ increased from $6 \mathrm{sec}$ in the group feeding the maximum ration to $13 \mathrm{sec}$ in the groups receiving 0 and $6 \mathrm{mg} / \mathrm{g} /$ day. In other words, the swimming speed of a well-fed $O$. striatus was $5.2 \mathrm{~cm} / \mathrm{sec}$, as against $2.4 \mathrm{~cm} / \mathrm{sec}$ for a starved fish.

The feeding rate of the test group receiving $60 \mathrm{mg} / \mathrm{g} /$ day averaged only $43 \cdot 3 \mathrm{mg} / \mathrm{g} /$ day, a value which confirms closely with the data $(43.2 \mathrm{mg} / \mathrm{g} /$ day $)$ reported by Pandian \& Vivekanandan (1976) for O. striatus. An amount of $43.3 \mathrm{mg} / \mathrm{g} /$ day may then represent the maximum which a $0.9 \mathrm{~g} O$. striatus can consume in the aquaria containing $15.5 \mathrm{~cm}$ depth of water at $27^{\circ} \mathrm{C}$.

Food absorption efficiency averaged $85.6 \%$ and did not appreciably vary between groups receiving different rations. This observation confirms the previous reports of Gerking (1955, 1971), Davies (1964), Pandian (1967b) and Pandian \& Vivekanandan (1976). Conversion efficiency $\left(K_{2}\right)$ increased progressively from $1.3 \%$ for those receiving $11.9 \mathrm{mg} / \mathrm{g} /$ day to $28.4 \%$ in those receiving $25.5 \mathrm{mg} / \mathrm{g} /$ day, and thereafter decreased to $20.3 \%$ in those receiving the maximum ration (Table $\mathrm{I}$ ). Conversion rate increased from $0.2 \mathrm{mg} / \mathrm{g} /$ day in the group receiving $11.9 \mathrm{mg} / \mathrm{g} /$ day to $7.2 \mathrm{mg} / \mathrm{g} /$ day in those receiving the maximum ration [Fig. 4(a)]. Geometric derivation of rationconversion rate relation obtained for $O$. striatus suggests that $10 \cdot 5,28 \cdot 0$ and $43 \cdot 3 \mathrm{mg}$ / $\mathrm{g} /$ day represents the maintenance, optimum and maximum rates, respectively.

The energy cost of maintenance has been determined in two ways; first, either the oxygen uptake (e.g. Beamish, 1964) or the weight loss (e.g. Savitz, 1971; Pandian \& Raghuraman, 1972) by the starving fish is estimated. Another method of measurement involves estimating the maintenance energy cost as equivalent to the ration consumed by the fish, which maintains constant body weight (Pentelow, 1939; Brown, 1946; Pandian \& Raghuraman, 1972). For instance, the starving O. striatus lost $6.3 \mathrm{mg} / \mathrm{g} /$ day, which may be considered as the minimum maintenance energy cost; to maintain its body weight without gain or loss, a ration of $10.5 \mathrm{mg} / \mathrm{g} /$ day has to be eaten by $O$. striatus, i.e. the group receiving maintenance ration was spending nearly 2 times more energy on metabolism.

Figure 5(a) presents the quantitative relation of food energy absorbed, metabolized for body functions and converted in $O$. striatus. The amount of energy expended by the fish above the maintenance cost of $10.5 \mathrm{mg} / \mathrm{g} /$ day is due to the specific dynamic 


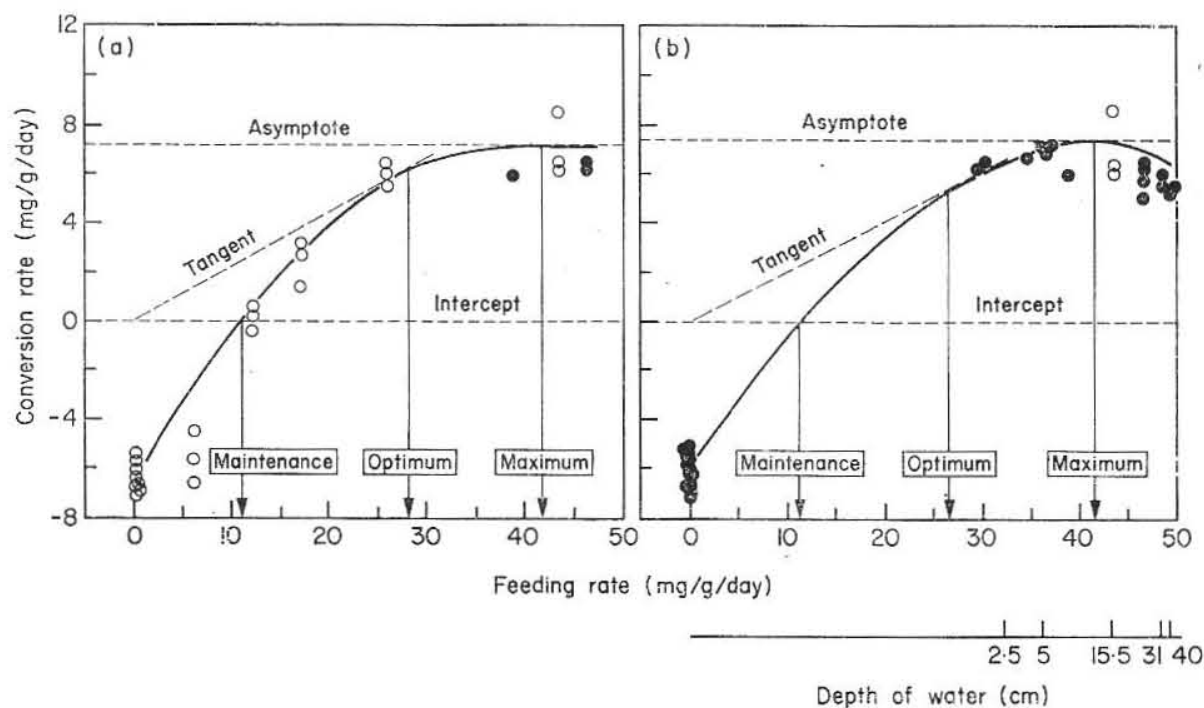

FIG. 4. Geometric derivation of various parameters of conversion rate (= growth) with accompanying feeding rate in the fish Ophiocephalus striatus $(0.90 \mathrm{~g})$ exposed to $15.5 \mathrm{~cm}$ depth of water at $27^{\circ} \mathrm{C}$ [given in (a)]. For comparison, data reported by Pandian \& Vivekanandan (1976) for $O$. striatus $(0.75 \mathrm{~g})$ exposed to aquaria containing different depths of water at $27^{\circ} \mathrm{C}$ are presented in (b). Data obtained by Pandian \& Vivekanandan for the group exposed to $15.5 \mathrm{~cm}$ water depth are indicated in closed circles in (a); data obtained for the corresponding group in this study are indicated in open circles in panel (b).

action (SDA) and excess swimming activity. The group feeding on the maximum ration of $43.3 \mathrm{mg} / \mathrm{g} /$ day expended on the SDA and excess swimming activity $28 \mathrm{mg} /$ $\mathrm{g} /$ day; it swam $439 \mathrm{~m} /$ day in comparison to that $(82 \mathrm{~m} /$ day) exhibited by the group receiving the maintenance ration of $12 \mathrm{mg} / \mathrm{g} / \mathrm{day}$. Therefore the excess swimming activity exhibited by the fish receiving the maximum ration is $439-82=357 \mathrm{~m} /$ day. The group receiving the optimum ration converted $6.1 \mathrm{mg} / \mathrm{g} /$ day at an expense of $10.5 \mathrm{mg} / \mathrm{g} /$ day on maintenance metabolism and only $5 \mathrm{mg} / \mathrm{g} /$ day on the SDA and excess swimming activity. To convert $7 \cdot 2 \mathrm{mg} / \mathrm{g} /$ day, the group receiving the maximum ration expended $10.5 \mathrm{mg} / \mathrm{g}$ /day on maintenance metabolism plus $17.9 \mathrm{mg} / \mathrm{g} /$ day on the SDA and excess swimming activity, i.e. the total energy cost (maintenance + SDA + swimming activity) of converting maximum ration is increased by 2 times, or if the SDA alone is considered, it increased nearly by $3 \frac{1}{2}$ times.

To assess the energy cost of the SDA and excess swimming activity in the groups receiving more than $25 \mathrm{mg} / \mathrm{g} /$ day, the data obtained by Pandian \& Vivekanandan (1976) on the quantitative relation of the feeding rate to the food energy absorbed, metabolized for body functions and converted in $O$. striatus exposed to different depths are presented in Fig. 5(b). The fish exposed to over $15.5 \mathrm{~cm}$ depth of water exhibited higher feeding rates (to $49 \cdot 1 \mathrm{mg} / \mathrm{g} /$ day) and lower conversion rates $(5 \cdot 5 \mathrm{mg}$ / $\mathrm{g}$ /day) than those exposed to $15.5 \mathrm{~cm}$. In this experiment, the minimum energy cost ranged from $5.8 \mathrm{mg}$ in the starving groups exposed to $2.5 \mathrm{~cm}$ depth to $7.4 \mathrm{mg} / \mathrm{g} /$ day in those reared in aquaria containing $40 \mathrm{~cm}$ depth of water [Fig. 4(b) and 5(b)]. Geometric derivation of ration-conversion rate relation suggests that the maintenance ration is $10.5 \mathrm{mg} / \mathrm{g} / \mathrm{day}$, which confirms the value obtained in this experiment. The groups exposed to 31 and $40 \mathrm{~cm}$ depth of water consumed $48.5 \mathrm{mg} / \mathrm{g} / \mathrm{day}$, converted 


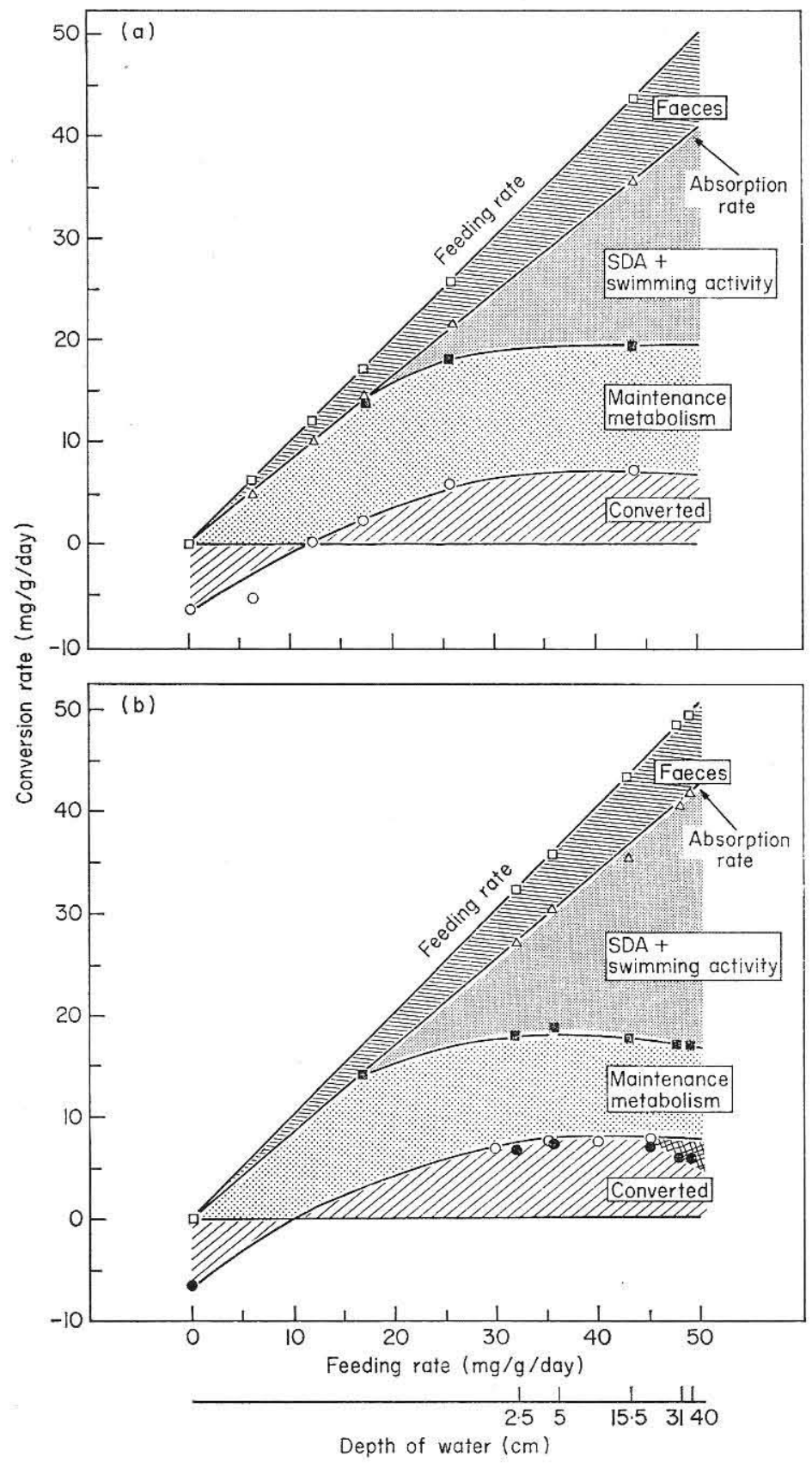

FIG. 5. Effects of feeding rates for scopes for conversion (= growth), metabolism (maintenance + Specific Dynamic Action and Swimming Activity) and output of faeces in young Ophiocephalus striatus fed on Tilapia mossambica muscles in aquaria containing $15.5 \mathrm{~cm}$ depth of water at $27^{\circ} \mathrm{C}$ [given in (a)]. For comparison, data obtained by Pandian \& Vivekanandan (1976) for $O$. striatus $(0.75 \mathrm{~g})$ exposed to aquaria containing different depths of water at $27^{\circ} \mathrm{C}$ are presented in (b). Data obtained in this study and the eye-fitted line $(-\mathrm{O}-\mathrm{O}-$ ) are also indicated in panel (b). Note the data of Pandian \& Vivekanandan for conversion rate in the groups exposed to 31 and $40 \mathrm{~cm}$ depth are lower than the expected values indicated by extending the trend obtained $(-\mathrm{O}-\mathrm{O}-$ ) in the present work. Though these groups exposed to 31 and $40 \mathrm{~cm}$ depths fed more than $43 \mathrm{mg} / \mathrm{g} /$ day, they converted less as they dissipated more energy in swimming longer distance. 
$5.6 \mathrm{mg} / \mathrm{g} /$ day at an energy cost of $35 \mathrm{mg} / \mathrm{g} /$ day, whereas the group exposed to $15.5 \mathrm{~cm}$ in this experiment as well as in that of Pandian \& Vivekanandan (1976) converted $7 \mathrm{mg} / \mathrm{g} /$ day at an energy cost of $28.5 \mathrm{mg} / \mathrm{g} /$ day. Those exposed to more than $31 \mathrm{~cm}$ depth of water expended only $20 \mathrm{mg} / \mathrm{g} /$ day on the SDA and excess swimming activity $(1158-116=1042 \mathrm{~m} /$ day; see Table I, Pandian \& Vivekanandan, 1976); the corresponding value for those exposed to $15.5 \mathrm{~cm}$ is $15.1 \mathrm{mg} / \mathrm{g} /$ day for the SDA and excess swimming activity $(357 \mathrm{~m} /$ day $)$.

I wish to express my gratitude to Dr T. J. Pandian for suggesting the problem and for valuable guidance. Financial support received from Sri Dhandayuthapaniswamy Temple, Palni is gratefully acknowledged. I also thank Mr S. Mathavan for help.

\section{References}

Beamish, F. W. H. (1964). Respiration of fishes with special emphasis on standard oxygen consumption. II Influence of weight and temperature on respiration of several species. Can. J. Zool. 42, 177-188.

Brett, J. R. (1972). The metabolic demand for oxygen in fish, particularly salmonids, and a comparison with other vertebrates. Respir. Physiol. 14, 151-170.

Brett, J. R., Shelbourn, J. E. \& Shoop, C. T. (1969). Growth rate and body composition of fingerling sockeye salmon, Oncorhynchus nerka, in relation to body temperature and ration size. J. Fish. Res. Bd Can. 26, 2363-2394.

Brown, M. E. (1946). The growth of brown trout (Salmo trutta L). 3. The effect of temperature on the growth of two-year old trout. J. exp. Biol. 22, 144-155.

Davies, P. M. C. (1964). The energy relations of Carassius auratus L. I. Food input and energy extraction efficiency at two experimental temperatures. Comp. Biochem. Physiol. 12, 67-79.

Engelmann, F. (1966). Energetics, terrestrial field studies and animal productivity. $A d v$. ecol. Res. 3, 73-115.

Gerking, S. D. (1955). Influence of rate of feeding on body composition and protein metabolism of bluegill sunfish. Physiol. Zoöl. 28, 267-282.

Gerking, S. D. (1971). Influence of rate of feeding and body weight on protein metabolism of bluegill sunfish. Physiol. Zoöl. 44, 9-19.

Johnston, I. A. \& Goldspink, G. (1973). A study of the swimming performance of the crucian carp Carassius carassius (L.) in relation to the effects of exercise and recovery on biochemical changes in the myotomal muscles and liver. J. Fish Biol. 5, 249-260.

Kinne, O. (1960). Growth, food intake and food conversion in a euryplastic fish exposed to different temperatures and salinities. Physiol. Zoöl. 33, 288-317.

Laurence, G. C. (1972). Comparative swimming abilities of fed and starved larval largemouth bass (Micropterus salmoides). J. Fish Biol. 4, 73-78.

Maynard, A. L. \& Loosli, K. J. (1962). Animal Nutrition. 5th edn. New York: McGraw-Hill.

Pandian, T. J. (1967a). Intake, digestion, absorption and conversion of food in fishes Megalops cyprinoides and Ophiocephalus striatus. Mar. Biol. 1, 16-32.

Pandian, T. J. (1967b). Transformation of food in the fish Megalops cyprinoides. II. Influence of quantity of food. Mar. Biol. 1, 107-109.

Pandian, T. J. \& Raghuraman, R. (1972). Effects of feeding rate on conversion efficiency and chemical composition of the fish Tilapia mossambica. Mar. Biol. 12, 129-136.

Pandian, T. J. \& Vivekanandan, E. (1976). Effects of feeding and starvation on growth and swimming activity in an obligatory air-breathing fish. Hydrobiologia (in press).

Pentelow, F. T. K. (1939). The relation between growth and food consumption in the brown trout (Salmo trutta). J. exp. Biol. 16, 446-473.

Savitz, J. (1971). Effects of starvation on body protein utilization of bluegill sunfish (Lepomis macrochirus Raînesque) with a calculation of caloric requirements. Trans. Am. Fish. Soc. 100, 18-21. 